\begin{tabular}{|c|c|c|}
\hline $\begin{array}{l}\text { PKS } \\
\text { PUBLIC } \\
\text { KNDOLEDGE } \\
\text { PROJECT }\end{array}$ & $\begin{array}{c}\text { REVISTA DE GEOGRAFIA } \\
\text { (RECIFE) } \\
\text { http://www.revista.ufpe.br/revistageografia }\end{array}$ & $\begin{array}{l}\text { OJS } \\
\text { OPEN } \\
\text { JOUNAL } \\
\text { SYSTEMS }\end{array}$ \\
\hline
\end{tabular}

\title{
TEODORO SAMPAIO: UM PRECURSOR DA CRIAÇÃO SIMBÓLICA DO NORDESTE?
}

\author{
Alcindo José de Sá ${ }^{1}$ \\ ${ }^{1}$ Professor Adjunto, Departamento de Ciências Geográficas - UFPE. E-mail: alcindo@ufpe.br
}

Artigo recebido em 22/10/2018 e aceito em 06/12/2018

\begin{abstract}
RESUMO
Como o próprio título sugere, o presente ensaio busca resgatar o geógrafo, ou melhor, o pensamento geográfico embutido no trabalho intelectual do "Engenheiro" Teodoro Fernandes Sampaio. Relevando a sua biografia e os seus escritos decorrentes da "expedição científica" ao rio São Francisco, em 1879, condensados na obra "O Rio São Francisco e a Chapada Diamantina", destacaremos o quanto esse trabalho é imprescindível para a compreensão do espaço/tempo de sua elaboração, bem como o conteúdo prospectivo nele existente para entendermos o presente. Na perspectiva de entender os sertões, que posteriormente vieram se chamar de nordestinos, Teodoro Sampaio descortina questões ambientes, étnicas/culturais (jaguncismo, religiosidade, coronelismo), de geografia física, imprescindíveis às ações institucionais do seu tempo, visando a construção de um Brasil moderno e "civilizado". Apesar de não ter atingido plenamente esses parâmetros, ao longo desses 129 anos, a vida e obra de Teodoro Sampaio nos lega um cabedal de referências que, seguramente, podem conduzir para a construção de um Brasil mais solidário e humano.
\end{abstract}

Palavras-chave: Teodoro Sampaio, Nordeste, sertões, imagético.

\section{TEODORO SAMPAIO: A PRECURSOR OF SYMBOLIC CREATION OF THE NORTHEAST?}

\begin{abstract}
As the title suggests, the present essay seeks to rescue the geographer, or rather, the geographic thought embedded in the intellectual work of the "Engineer" Teodoro Fernandes Sampaio. Recalling his biography and his writings resulting from the "scientific expedition" to the São Francisco River in 1879, condensed in the work "The São Francisco River and the Chapada Diamantina", we will highlight how much this work is essential for the understanding of the space/time context of its elaboration, as well as its prospective content in order to understand the present. In the perspective of understanding the "sertões" (backlands), which later came to be called the Northeastern Backlands, Teodoro Sampaio reveals environmental, ethnic and cultural issues (banditism, religiosity, caudillism), indispensable to the institutional actions of his time, aiming at the construction of a modern and civilized Brazil. Although it has not fully reached these parameters, during the last 130 years, the life and work of Teodoro Sampaio is a source of references that can surely lead to the construction of a more solidary and humane Brazil.
\end{abstract}

Keywords: Northeast of Brazil, historical geography, backlands. 


\section{INTRODUÇÃO}

Em um contexto de genialidade, William Shakespeare, talvez, vislumbrando o mundo fugaz, do esquecimento rápido, desmemoriado pós-moderno, afirmou, que "atiraríamos o passado ao abismo, mas não nos inclinamos para ver se está bem morto”. Essa assertiva seguramente tem o seu lastro na ascensão da veloz história do tempo racional/maquínico capitalista como telos, destino inabalável, sem considerar esse processo, como bem ressalta Paulo Freire (1987), "em que os homens dentro da sociedade vão respondendo os desafios do mundo e vão temporalizando os espaços geográficos".

Todavia, o mundo "pós-moderno" pautado no "meio técnico-científico-informacional" (SANTOS, 1996) mesmo propositalmente esquecendo as humanas temporalizações diversas, como resposta aos seus desafios, não consegue apagar os resquícios do passado no presente, já que é partícipe do próprio presente. Sendo assim,

"tudo seria muito fácil se com um não puro e simples aniquilássemos o passado.

Mas o passado é revenant por essência. Se o jogamos fora ele volta, volta irremediavelmente. Por isso a única forma autêntica de superá-lo é não desprezá-lo. Contar-se com ele. Orientar-se por ele, para poder evita-lo. Em resumo, viver 'a altura dos tempos', com consciência heperestésica da conjuntura histórica" (ORTEGA Y GASSET, 2002, p.128).

Ressaltamos tais digressões históricas/filosóficas, à luz do brilhante e ao mesmo tempo esquecido engenheiro, historiador e geógrafo Teodoro Fernandes Sampaio. Se o passado é revenant por essência, se volta irremediavelmente, podemos situar o trabalho intelectual, espiritual e moral do referido personagem coma uma referência viva de quem pensou de maneira "positiva" e buscou construir espaços geográficos em prol de um Brasil forte, dinâmico, mesmo que encaixado nos propósitos do emergente mundo em ascensão do capitalismo mundial de caráter imperialista.

Quando hoje se fala em custo Brasil, não podemos esquecer que se trata, acima de tudo, de um custo territorial; de quanto os objetos, os sistemas de engenharia, degradados ou não, encarecem ou barateiam o intercâmbio comercial e, consequentemente, a qualidade de vida cotidiana do seus habitantes, Teodoro Sampaio, em várias de suas ações como engenheiro, cartógrafo, historiador e geógrafo, buscou de forma pragmática ou intelectual, compreender os sistemas de objetos do espaço nacional, bem como agir na construção do mesmo de maneira a dotá-lo de condições mínimas de cidadania, a exemplo da sua ação como engenheiro-chefe da repartição de águas e esgoto de São Paulo (1898), engenheiro contratado 
pela Prefeitura de Salvador para a realização de obras de saneamento e abastecimento de água (1905), engenheiro de primeira classe nas obras de prolongamento da estrada de ferro da Bahia ao São Francisco (1882), etc. (SAMPAIO, 2002, p.44-45). Assim, relevando aspectos bibliográficos e destacando a obra "O Rio São Francisco e a Chapada Diamantina", fruto de uma expedição ao referido rio, buscaremos situar Teodoro Sampaio não apenas no espaço/tempo do período de sua existência, mas, também destacar o seu legado na dinâmica do espaço/tempo presente.

\title{
OBJETIVO E REFENCIAIS TEÓRICO E METODOLÓGICO
}

Este trabalho parte do princípio que a história, longe de ter chegado a um fim, continua, como bem assinala Freire (1987, p.56), em um processo dinâmico e, portanto, em constante realização, "já que os homens dentro da sociedade vão respondendo aos desafios do mundo e vão temporalizando os espaços geográficos". Esta temporalização, cremos, se expressa nas diversas estruturas, processos, formas e, principalmente, funções concretas e simbólicas que as novas circunstâncias da história demandam; exigem respostas. Estas, digamos, se imbuem de intencionalidades ideologicamente manipuladas ou não, de projetos, que para serem executados exigem tanto o trabalho intelectual dos agentes individuais da história, quando de trabalhos manuais solitários ou coletivos.

Nesse sentido, como nos assevera Ortega e Gasset (1989, p.31-32):

\begin{abstract}
"se a história que é a ciência das vidas humanas, fosse ou pudesse ser exata, significaria que os homens eram pederneiras, pedras, corpos físico-químicos e nada mais. Mas então, não haveria nem história nem física, porque as pedras, mais ditosas, se assim quiserem, do que os homens não precisam de fazer ciência para ser o que são, isto é, pedras. Em troca, o homem é uma entidade estranhíssima que para ser o que é necessita antes averiguá-lo, necessita, queira ou não, perguntar-se o que são as coisas ao seu redor e o que ele é em meio às coisas... O essencial no homem é, em troca, não ter outro remédio que esforçar-se em conhecer, em fazer ciência, melhor ou pior, em resolver o problema de seu próprio ser e para isso o problema de que são as coisas entre as quais inexoravelmente tem que ser. Isto: que necessita saber, que necessita - queira ou não - afanar-se com seus meios intelectuais, é o que constitui indubitavelmente a condição humana"
\end{abstract}

Eis o nosso referencial teórico: que a história, contraditória e dialética, é a ciência das vidas humanas e que, para tanto, o homem como uma entidade estranha necessita, para sua existência, para a sua temporalização geográfica, perguntar, estudar e analisar o que são as coisas ao seu redor, o espaço ao seu redor, na busca de entender o que ele é em meio ás 
coisas. Ao elegermos, neste ensaio, o trabalho intelectual do "esquecido" geógrafo Teodoro Sampaio, buscaremos, considerando a geografia e a história, como ciências das vidas humanas, relevar a sua pessoa, a sua existência, através dos seus trabalhos intelectuais com perguntas em busca de respostas sobre o que foram as coisas ao seu redor e o que ele foi em meio as coisas, em buscas de um Brasil mais humano e solidário.

\section{TEODORO SAMPAIO: VIDA, UM POUCO DE SUA OBRA, CONDICIONANTES IDEOLÓGICOS E LEGADO}

Fruto de uma sociedade, na sua gênese, iníqua e preconceituosa, nasce numa senzala o Engenheiro Canabrava, pertencente ao visconde de Aramoré, no município de Santo Amaro-BA, Teodoro Sampaio, tendo como pais a escrava Domingas da Paixão do Carmo e o padre Manuel Fernandes Sampaio. Em 1864 é levado pelo pai para estudar em São Paulo e, depois, no Rio de Janeiro, onde se forma em engenharia no ano 1877. Volta a Santo Amaro, onde revê a família (mãe, irmãos), comprando em 1878, a carta de alforria do seu irmão Martinho, gesto repetido com os irmãos Ezequiel (1882) e Matias (em 1884). Teodoro não foi escravo, já que era filho de pai branco. Por pertencer a uma pequena "elite" negra que já despontava, em especial na Bahia, nos idos do Século XIX, particularmente vinculada à educação e comércio, e o fato da mestiçagem branca, Teodoro Sampaio, digamos, assimila os princípios "iluministas positivos" de fé na ciência e no conhecimento como condição pessoal e coletiva de redenção de estruturas de pobreza e caminho para "ordem e progresso", como se vislumbra na sua obra "O Rio São Francisco e a Chapada Diamantina”.

Repetimos, quando hoje se discute a importância dos sistemas de engenharia para a nossa autonomia técnica-científica e informacional, evitando o tão propalado encarecimento do custo Brasil, Teodoro Sampaio em 1893 “elabora, juntamente com Sales de Oliveira e o coronel Jardim, o regulamento da Escola Politécnica de São Paulo", hoje pertencente à Universidade de São Paulo - USP, uma das maiores referências nas áreas de engenharia no Brasil e, quiçá, do mundo. Enfim, uma visão prospectiva mirando um país menos colonizado e mais ciente dos seus potenciais humanos e ambientais.

Neste período findo do Século XIX e início do Século XX, o Estado de São Paulo e sua capital assumem o segundo posto em importância econômica/cultural no território brasileiro e, para tanto, mirando "um progresso alvissareiro", foram criadas várias instituições ligadas às atividades científicas, das quais são exemplos: a Comissão Geográfica e Geológica 
de São Paulo (1886), o Instituto Agronômico de Campinas (1887), o Instituto Bacteriológico de São Paulo (1892), a escola Politécnica de São Paulo (1893), o Museu Paulista (1894) e o Instituto Butantã (1901) (SAMPAIO, 2002, p18). Para dinamizar esses centros de ensino e pesquisa, agregaram-se geólogos, como o norte americano Orville Derby, tido como o pai do ensino geológico no Brasil, Francisco de Paula Oliveira, Gonzaga de Campos e Eugênio Hussak: químicos, como W. F. Dafert; engenheiros, como Teodoro Sampaio e Euclides da Cunha; Botânicos, como Alberto Loefgren; zoólogos, como Hermann von Lhering; médicos, como Adolfo Luiz e Vital Brasil. Escrevendo, em 1902, sobre as dinâmicas e os "melhoramentos" vividos pela capital paulista, Teodoro Sampaio se manifesta de maneira entusiástica pelo surgimento de

“verdadeiros palácios para as escolas públicas, para a escola Normal, para a Escola Politécnica, para as secretarias de Estado; demonstra-se ainda pela atenção especial que se dedica à saúde pública, iniciando-se obras de saneamento na capital [...] hospital de isolamento que é um exemplo no gênero; instituto vacinogênico, desinfetórios, institutos bacteriológicos e de análise química, farmácia do Estado, quase todos instalados construídos a caráter [...] A Escola Politécnica torna-se, dirigida pelo Dr. Antônio Francisco de Paula, uma instituição-modelo; a Comissão Geográfica e Geológica, que vinha desde o império, sob a direção do notável homem da ciência. O Dr. Orville Derby, é dotada mais largamente e alarga o círculo das suas investigações científicas; o Museu paulista, dirigido por um naturalista dos mais competentes, o Dr. Hermann von Lhering, instala-se no monumento do Ipiranga e enriquece as suas coleções" (SAMPAIO, 2002, p.19)

A propósito da construção desses novos "ambientes", em 1879, Teodoro Sampaio fez parte da Comissão Hidráulica para estudar os portos e a navegação interior do Brasil. Nela "apresentou, estudou e projetou os melhoramentos do Porto de Santos, os do Rio São Francisco, no curso superior da Cachoeira de Paulo Afonso até a de Pirapora, em Minas Gerais" (CINTRA, et al, p.3). Em 1894 é um dos membros fundadores do Instituto Histórico e Geográfico de São Paulo e engenheiro responsável pela edificação de seu prédio. Em 1898 é nomeado engenheiro-chefe da Repartição das Águas e Esgotos de São Paulo e torna-se sócio do Instituto Geográfico e Histórico da Bahia. Em 1901 sai a publicação de "O Tupi na Geografia Nacional”. Em 1902 torna-se sócio do Instituto Histórico e Geográfico Brasileiro. Enfim, são inúmeros feitos e circunstâncias participativas que indicam a personalidade de um ser engajado na construção de um território melhor; um ser, como nos assevera Ortega y Gasset (1989, p.31) que soube perguntar “o que são as coisas a seu redor e o que é ele em 
meio as coisas". Isso parece bem evidente em uma de suas obras, que procuraremos destacar nesse ensaio, intitulada "O Rio São Francisco e a Chapada Diamantina".

Teodoro Sampaio, pela trajetória de vida evidente no seu legado, respondendo ao que ele é em meio às coisas, parece desnudar uma profunda consciência e vontade de separação das injustiças reinantes na sociedade de então: oligárquica, escravista, preconceituosa e não tanto afeita aos ares desenvolvimentistas que espraiavam nalguns países centrais e periféricos, a exemplo da Inglaterra e dos EUA no Século XIX. Porém, transparece que não era uma rebeldia engajada em algum movimento social que visasse uma metamorfose estrutural de classe e, por consequência, de um território para uso mais equânime como instância produtiva e de espaços de vida. Ele parece advogar um espaço mais humano e solidário através de ações de pessoas e instâncias dotadas de visões esclarecidas. Um humanismo, digamos, ditado por iluminados que aos poucos, e com muita dificuldade, iria se espraiar pelo território. O referido geógrafo, pela sua capacidade intelectual, busca de direito, se enquadrar - e consegue - na burocracia da sociedade "aristocrática" reinante, superando preconceitos, assim como outros mestiços a exemplo de Machado de Assis, etc. Isso fica evidente quando ele se orgulha de sido aceito e lidado com "brancos" em plano de igualdade. Portanto, assim como os demais iluminados, assume os preconceitos da ciência como a fonte de busca de verdades em todas as dimensões físicas e humanas e, a partir delas, a efetivação de planejamento de ações precisas na construção de espaços mais eficientes e pragmáticos, o que, numa visão positiva, significariam melhores. Isso vai requerer um distanciamento do sujeito do objeto análise; a completa exteriorização do "meio ambiente" uma descrição minuciosa do entorno do ser, sem o mesmo se achar partícipe, pois sua participação somente se daria pela instrumentalização das verdades científicas/abstratas do que são as coisas ao seu redor. Todavia, ressaltamos, sem invalidar esse conhecimento, repetimos, que amalgamava uma formação territorial e que, como veremos, continua nas entranhas da territorialidade hoje presente.

Assim, dotado dessa "psicoesfera" (SANTOS, 1996) científica, Teodoro Sampaio, ávido por conhecer o Brasil e subsidiar no seu desenvolvimento, elabora estudos preciosos no campo da cartografia, da geologia, da antropologia, da linguística, da botânica, da sociologia, da economia, da ecologia, etc. Foram estudos que subsidiaram inclusive a feitura de "Os Sertões", trabalho intelectual proeminente de Euclides da Cunha, escrito nos primórdios do Século XX. No livro "O Rio São Francisco e a Chapada Diamantina” encontramos, de forma pioneira, relatos primorosos de trabalhos de campo que trazem a lume o que posteriormente veio a se amalgamar como o imagético discurso da Região Nordeste: a pobreza retirante 
"indolente" e preguiçosa, o misticismo religioso e a violência do coronelismo e do jaguncismo.

O referido livro foi fruto da participação de Teodoro Sampaio na comissão de engenheiros com o intento de estudar "os melhoramentos dos portos do Brasil e a navegação interior dos grandes rios" que desaguavam na costa oriental, montada em 1879 pelo conselheiro Cansansão de Sinimbu, então à frente do governo, sobre a direção do engenheiro americano William Milnor Roberts. Era uma comissão numerosa e "visava não só aqueles problemas de indiscutível alcance nacional, como, também, se destinava ao preparo de profissionais brasileiros que, no futuro, teriam de dirigir trabalhos conducentes à solução dos sobreditos problemas" (SAMPAIO, 2002, p.55). Ou seja, no contexto de um Brasil modestamente se inserido no mundo do capitalismo industrial e da ascensão da crença da verdade científica como elo indispensável ao progresso, situa-se esse "grupo" em busca de solucionar problemáticas nacionais.

No início do longo percurso pelo São Francisco, Teodoro Sampaio destaca questões marcantes no cenário sócio-espacial brasileiro que, posteriormente, veio a se denominar o Nordeste brasileiro: a pobreza, o flagelo da seca e o vagar dos retirantes. Atinando-se ao panorama geográfico da cidade de Penedo/AL, às margens do São Francisco, ele destaca:

“a população da cidade estava então muito aumentada com a gente emigrada dos sertões assolados pela seca. Viam-se nas ruas muitos povos famintos e sem trabalho, levas de mendigos andrajosos esmolando ou estendidos pelo chão à sombra das árvores, homens que foram robustos, pelos tipos de uma adaptação admirável, como se foram esqueletos vestidos de couro... A fome, que os tinham depauperado e dizimado aos centos, cedera lugar agora à varíola, que devorara famílias inteiras destes degraçados que de tão longe, fugindo às misérias da seca, tinham vindo procurar socorro às margens do grande rio... O São Francisco, como uma oásis no deserto, através dos sertões da Bahia ao Ceará, de Pernambuco ao Piauí é, na verdade, a terra da promissão e o refúgio daqueles povos assolados pela seca prolongada e periódica... Penedo demonstrava-o cabalmente com a sua numerosa população de retirantes" (SAMPAIO, 2002, p.65-66).

Se hoje no cenário territorial nordestino a fome e a miséria ainda constituem elementos marcantes, há quase 130 anos o referido geógrafo nos descreve esse quadro de maneira pungente, muito embora sem tocar nos fatores sociais e históricos à sua feitura e funcionalidade. E nos atendo ao presente, denota-se que nessa escala espaço/temporal poucas ações políticas efetivas foram executadas com vista à superação estrutural das desigualdades sócio-territoriais vigentes nesse fragmento do território brasileiro. Como outrora, o São 
Francisco é pintado como a redenção nordestina, seja através do estabelecimento de grandes empreendimentos agropecuários (extremamente capitalizados e seletivos), seja como fonte de abastecimento ao semiárido pelos grandes sistemas de engenharia de "transposição". Como outrora, o problema sertanejo é a carência de água, não de estruturas sócio-espaciais e de uso da "escassa água" de maneira mais racional.

Buscando socorrer os desvalidos, os mendigos e retirantes vitimados pela seca em 1879, Teodoro Sampaio destaca as políticas assistencialistas periódicas, implementadas pelo governo central, através das "frentes de emergências". Observando as paisagens de Piranhas, município situado logo após Penedo, ele destaca:

"havia aí então muito povo. O mulherio era extraordinário; e isso se explica pelo afluxo dos retirantes do alto sertão que a seca prolongada expelira dos seus lares. A população masculina estava espalhada ao longo da linha férrea em trabalhos de construção, enquanto o elemento feminino e as crianças permaneciam na sede onde se lhes distribuíam em mantimentos parte dos salários ganhos por seus pais e maridos empregados nos serviços da estrada... As habitações eram poucas para tanta gente. Improvisaram-se ranchos de palhas, pequenas tentas fechadas com esteiras, tudo quanto era possível imaginar-se para agasalhar a população excedente ou adventícia... Chegávamos exatamente na ocasião em que se distribuíram os socorros pela população faminta no barracão próximo à estação da estrada ferro. $\mathrm{O}$ aspecto dessa gente não negava o sofrimento por que tinha passado. As mulheres e as crianças macilentas, sujas, e com as roupas em farrapos, assentadas pelo chão, traiam um sofrimento que os primeiros socorros não lograram totalmente extinguir... Mais a fraqueza e debilidade do que a impaciência no receber o minguado socorro, vagarosamente distribuído, davam-lhe um aspecto triste, desconsolado e doentio... Entretanto , quanta miséria, quanta desgraça, quanto infortúnio como esse minguado socorro se pouparam?"“(SAMPAIO, 2002, p.73).

No espaço/tempo presente, apesar dos inúmeros avanços no que respeita a inclusão sócio-espacial da população nordestina, é sobejamente conhecido o legado de pobreza a que ainda está submetida vasta parcela da sociedade. Para ela, se as frentes de emergência não são mais minguado socorro, as políticas de cunho assistencialistas - ou clientelistas para alguns como bolsa-família, vale-gás, etc. tem lhe poupado do total infortúnio da miséria. Como se ver, muito do passado, continua a vigorar na nossa geografia humana.

Destacando o aspecto etnográfico desse povo "sofredor" sertanejo à margem do São Francisco, Teodoro Sampaio afirma que

"vê-se ali, entre eles todos os matizes da população policroma da nossa terra. O caboclo legítimo, o negro crioulo, o cariboca, misto de negro e do índio, o cabra, o 
mulato, o branco tostado de cabelos castanhos e às vezes ruivo todas as raças do continente e os produtos dos seus diversos cruzamentos ali representados... Neste particular, é o vale do São Francisco um vasto cadinho em que todas as raças representadas na América se fundem ou se amalgamam... Os mestiços eram contudo muito mais numerosos. Estatura pouco acima da meã, cabelos crespos ou anelados, pretos sob um chapéu de couro redondo e de abas curtas, descida podendo servir este a um tempo de estojo e de cuia para beber água, dentes bons, curtos, firmes, cortados em ponta como os do peixe, que é este chic do sertanejo, pescoço curto e grossa, ombros largos, bom peito, desbarrigado, canelas finas e pé curto, tal é o cabra do sertão a quem não falta a palavra fácil, a rapidez da réplica, a vivacidade, a imaginação e a poesia. " (SAMPAIO, 2002, p.95).

Em um formato romanceado, o referido autor descreve o homem sertanejo, como até hoje está fixado no imagético não somente nordestino, como também, nacional. Se observarmos os materiais de divulgação turística, as imagens televisivas em novelas e outros meios de comunicação, apesar da diversidade racial, o nordestino quase sempre é identificado como o cabra sob um chapéu de couro redondo e de abas curtas "a quem não falta a palavra fácil, a rapidez da réplica, a vivacidade, a imaginação e a poesia”.

Na geografia vivida por esses cabras,

"as habitações se sucede a miúdo, formando pequenas povoações, lugarejos insignificantes e algumas vilas e cidades. Nas povoações ribeirinhas, o aspecto de pobreza e de atraso é extremo. Vive-se aí sem se saber de quê. Não se vê agricultura alguma, nem trabalho permanente. Na beira do rio, no lameiro das margens, onde a humidade resiste melhor à secura do ar, descobrem-se às vezes os restos de uma plantação de milho, de abóboras, de batatas doces, e mandioca, mas tudo em proporções minúsculas e muito pouco cuidadas. Nas catingas, reconhece-se que o gado ali pasta pelo rasto da rês que passou, porque raras são as cabeças que passou.... Nestas paragens, o deserto é apenas aparente. O Brasil, em verdade, é mais habitado do que se pensa e menos rico do que se presume" (SAMPAIO, 2002, p.97).

Nos atendo ao presente, como as próprias estatísticas pontuam, a miséria e a pobreza estampadas nos habitats (cidades, vilas e povoações), ainda são grandes máculas no território sertanejo, porém, a que se destacar que hoje, sim, se vê agricultura tanto nas áreas de sequeiro, quanto nos grandes projetos de irrigação ao longo do São Francisco; e na caatinga o gado é abundante, inclusive trazendo sérios transtornos ambientais ao frágil ecossistema. $\mathrm{O}$ atraso já não é mais extremo e grande parcela da população, mesmo vivendo "sem saber de quê", atualmente está inclusa "nos programas sociais" das diversas instâncias de governo. Deve-se destacar que o Nordeste, segundo inferições estatísticas oficiais, é uma das regiões que mais cresce no país, denotando, no presente, não somente ser bem habitada, como mais 
rica "do que se presume". De maneira premonitória, ao passar por Juazeiro/BA e Petrolina/PE, um aspecto geográfico dos mais dinâmicos na história presente do país nas redes globais do agronegócio, Teodoro Sampaio destaca: "notamos na população de Juazeiro a mais obsequiosa atenção e urbanidade... Apesar da distância e dos meios de transporte e das dificuldades vencidas chegam aqui as mercadorias europeias por preços bem razoáveis" Já sobre a "vila de Petrolina" o mesmo frisa:

“algumas casas de feia construção ao longo de umas poucas ruas estreitas, desalinhadas e areentas, uma igreja de modestíssima aparência, pouco comércio, população escassa, eis o que era Petrolina, que aliás, todos informavam ser uma população muito nova e destinada a grande futuro, vaticínio decerto muito problemático, atenta as condições da localidade e dos sertões. De sua mais direta dependência” (SAMPAIO, 2002, p.104-105).

Vaticínio decerto problemático, mas que a história mostrou ser superado, relativamente, pelo advento das forças como ressalta (SANTOS, 1996) do interno e do externo, do Estado e do mercado, do novo e do velho.

A propósito, do "velho", Teodoro Sampaio, nesse pioneiro e valioso "trabalho de campo", não deixa de tocar em três temáticas que, segundo Albuquerque Júnior (1996), marcam o imagético/discursivo nordestino até o presente: a religiosidade, o coronelismo e o cangaço/jaguncismo. Ao visitar o santuário de Bom Jesus da Lapa/BA, ele discorre:

“eram seis e meia horas da manhã, quando galgamos a escada que nos conduz ao átrio. Tocamos aí o sino como sinal de romeiro à porta e logo apareceu-nos o sacristão, que no-la abriu o por onde entramos na capela já ocupada já ocupada por uma multidão andrajosa e chagada, homens, mulheres e meninos exibindo as suas deformidades, as suas úlceras, e as suas misérias, pedindo, clamando, atravessando o seu braço descarnado para nos tomar o passo, rogando suplicando impertinentemente, incansavelmente... Logo ao entrar, o efeito que o experimenta o visitante é extraordinário e emocionante. O expectador entra logo em trevas, a dois passos da entrada, mas divisa logo, no fundo da gruta, iluminados por uma luz discreta, que entra por uma fresta envidraçada à direita, os três altares dourados, mas singelos, onde estão imagens e no meio a do crucificado Senhor Bom Jesus da Lapa, consolo e remédio dos que crêem e dos que têm, fé... Os companheiros de viagem, muitos deles protestantes, não puderam negar o efeito surpreendente e emocionante no santuário do Bom Jesus da Lapa... A fé o proclama, a natureza prodigiosa o serve" (SAMPAIO, 2002, p.137-138)

Ópio do povo, ou não, o referido autor toca em um ponto, demasiado marcante no "concreto" e imaginário sertanejo: a proclamação da fé. No passado e no presente, uma multidão andrajosa, pobre, doente e miserável faz das suas crenças religiosas um refúgio 
inexorável as suas minguadas expectativas de vida; vida tecida, digamos, não por um projeto historicamente inclusivo e cidadão, mas, como no medievo, um destino, um fatalismo, intencionalmente forjado "pelas significações imaginárias" de uma elite oligárquica que adorava ovacionar "as manifestações, as tradições populares. Hoje Bom Jesus da Lapa é ainda um grande centro de referências da fé, incluindo-se ainda nesse rol Juazeiro do Norte/CE, São Francisco do Canindé/CE, etc.

Associado ao poderio dessa fé, Teodoro Sampaio destaca, ouvindo relatos, o poderio político manipulador dos coronéis, ávidos não apenas pela posse dos latifúndios, mas de qualquer outra fonte de renda que lhe agregue mais poder, inclusive de do aparato religiosos. Ao contexto de Bom Jesus da Lapa, o referido autor destaca que

"as humildes funções de sacristão eram objeto malicioso informante, vivem a fazer política para guardarem para si essas funções, razão por que dificilmente aqui pára um capelão, não se tolerando a presença de vigário... Contou-nos, então, por que motivo o lugar, apesar de populoso, nem sequer se elevava a paróquia e muito menos a vila. 'Essa gente não quer fiscais', dizia, 'não quer prestar contas a ninguém. A coisa assim mesmo é que serve... porque, não só dá para viver a muita gente, como até dá para se fazerem eleições” (SAMPAIO, 2002, p.139).

Não é de todo estranho esse contexto ainda presente nos tempos presentes, em todo território nacional, e não somente nordestino. Se a figura do coronel, o quase donatário de um poder absoluto, nos micros e macro poderes, saiu da cena, ainda se fazer atuantes pressões de pessoas e grupos vinculados a famílias tradicionais, que manipulam inúmeras esferas de poder nas escalas municipais estaduais e federais. Coelhos, em Petrolina/PE, Magalhães na Bahia, Sarneis no Maranhão, são exemplos notórios.

Nesse território onde as pessoas assumem papel de verdadeiras instituições; onde a sua palavra é "lei", torna-se espaço fértil para a disseminação da violência, inclusive a exercida pelos "contrapoderes" de jagunços e cangaceiros. Ao chegar em Januária/MG, diz Teodoro Sampaio,

"que reinava a cidade um lúgubre silêncio. Era grande o terror entre os raros moradores que tinham permanecido e que, assustados, nos olhavam com desconfiança e se ocultavam logo. As ruas estavam desertas, as casas fechadas, o comércio recolhido, as autoridades fugitivas, reinava o desânimo e o abandono era completo... Quem não logrou fugir rio acima, acompanhado da força pública, as autoridades e as pessoas de mais crédito que se punham assim ao abrigo da sanha do Neco e dos seus sequazes, ganhou a catinga, refugiou-se nos matos próximos até ver em que paravam as coisas... O Neco indubitavelmente triunfava em toda a linha. $\mathrm{O}$ seu nome inspirava terror, e, por isso, quem não fugiu da Januária é porque contava 
de qualquer modo com sua proteção ou amizade... A gente do Neco, isto é, o seu exército de jagunços, entrou na cidade e fez o que quis... Estávamos de faro num mundo estranho. Como estava longe, oh, civilização!... Diante daquela afronta, a autoridade, uma sombra, tinha desaparecido... Sem força, sem recursos, não podendo mesmo contar com estes ainda quando instantemente solicitados a autoridade, nestes sertões tão apartados, não faz outra coisa senão o que lhe dita uma prudência hábil em tal emergência - não foge, ausenta-se - (SAMPAIO, 2002, p.153-167)

Talvez hoje reine nas cidades nordestinas - e por que não dizer, em todas brasileiras - um lúgubre silêncio, não decorrente dos jagunços, cangaceiros clássicos, mas do "medo urbano" (BAUMAN, 2004) de um mundo de seres teleguiados pela competição, o hedonismo, o ter aqui e agora a reboque de todos os parâmetros morais e éticos. Se nos atermos aos índices de criminalidade no Brasil, percebemos que, como outrora, instituídos pelos poderes públicos e privados, os novos jagunços do consumo legal e ilegal afrontam autoridades, e estas, em muitas circunstâncias, ausentam-se.

Neste "ambiente" humano, Teodoro Sampaio também dispensou uma atenção pioneira Á questão ambiental física/humana. Ainda perto de Januária/MG, ele destaca:

"as terras têm aqui pouco valor, de fato, muito pouco valor. Os proprietários cedemnas gratuitamente aos moradores pobres para fazerem suas plantações e estes obtêm quando desejam, derrubando matas, tirando madeira em verdadeira devastação... São aqui terríveis as formigas, as quais inutilizam área considerável de terreno próprio para cultura, e só próximo às barracas do rio é que as suas devastações são menos sensíveis. Por essa razão, as culturas se fazer todas nas margens e a mor parte dos proprietários do solo se dedicam de preferência à criação do gado... Nestes sertões, o homem pobre nunca é suficientemente pobre que precise viver do salário. O mundo aqui é largo demais para que se faça sentir a pressão das necessidades... A natureza pródiga não deixa haver a verdadeira pobreza que force a trabalhar e que obrigue e mantenha a disciplina pela necessidade de viver... Não há aqui, tampouco, estímulo para capitalizar. Vive-se bem, vive-se ao natural, sem cuidados pelo futuro, porque a pobreza aqui não aterra a ninguém (SAMPAIO, 2002, p.142-175).

Vemos quanto, dada.

Para finalizar, cremos ser oportuno também ressalvar os veios de geógrafo físico e biogeógrafo, encontrados nos escritos de extrema erudição e poesia (sim, ciência também pode ser feita sem frieza e total impessoalidade), de Teodoro Sampaio. Acerca da paisagem do Rio das Velhas/MG ele declara: "prolongando na direção do sueste o largo sulco que o São Francisco abriu em mais de meio horizonte, o vale do rio das Velhas com sua planície baixa, manchada de negro, que parece fugir-nos por uma quebrada junto ao esporão aplainado a que 
se dá o nome de serra do Corumbataí, assinala-nos uma região com aspecto de um campo deixado à lavoura do futuro... A nossos pós, o terreno coberto de gramíneas altas e sombreado de árvores raras, dispersas, deixa-nos bem patente o dorso, levemente ondeado, da chapada em cujas dobras úmidas cresce copado e vigoroso o buriti, orlando de verde os brejais, acompanhando com um aléia de palmas esféricas o curso dos ribeiros minúsculos que deslizam pelas encostas e vão engolfar-se na planície lá embaixo... Como é belo esse Brasil Central que tão poucos conhecem e de que nós, brasileiros, tão ingenuamente ufanamos, exagerando os recursos! (SAMPAIO, 2002, p.184-185).

Sim, como outrora, este vasto e belo Brasil continua desconhecido para parcela significativa de brasileiros, que tão ingenuamente muitas vezes se ufana. Como outrora, continua a ser um país com recursos vastos, exagerados mesmo (temos a maior floresta equatorial do mundo, a maior reserva de ferro do mundo e tantos outros recursos em potencial), mas, infelizmente, para usufruto de uma elite nacional e global que pouco rateia os lucros advindos com as suas explorações e exportações, com os nacionais, brecando-os das possibilidades de conhecerem e viverem o seu território sem ufanismos ingênuos. Enfim, de maneira premonitória, Teodoro Sampaio quis dizer: o Brasil não conhecia o Brasil, fato que continua a perdurar e precisa ser revertido, para que sua população, imbuída de cidadania possa um dia exclamar: como é lindo esse Brasil Central que todos nós conhecemos!

\section{CONLUSÕES}

Podemos inferir que, numa perspectiva Gasseteana, o engenheiro, cartógrafo, geógrafo e linguista Teodoro Fernandes Sampaio foi um ser que soube fazer história, na medida em que na sua trajetória de vida e intelectual foi um ser que sempre soube questionar o que são as coisas a seu redor e o que foi ele em meio as coisas. Para tanto, como mestiço, filho de escrava com um branco, desde a sua infância e com o lastro paterno numa sociedade escravista, buscou uma formação que lhe permitisse se inserir socialmente e intelectualmente numa condição menos discricionária. A sua formação de engenheiro lhe permitiu entrar nas instâncias burocráticas em plano de igualdade com os brancos no estudo e execução de obras infra-estruturais, em um ambiente no qual o Brasil, incipientemente, ascendia no mundo "moderno" da técnica, da ciência e da informação. Neste contexto fez viagens de explorações no bojo comissões científicas, como a da Comissão Hidráulica, encarregada de estudos para o melhoramento do porto de Santos e de do Rio São Francisco. Nesta última realiza um trabalho minucioso sobre a geografia física, a etnografia, a biogeografia, a economia, enfim, a 
dinâmica sócio-espacial do que, posteriormente veio a se denominar, os sertões nordestinos; este trabalho encontra-se condessado na obra "O Rio São Francisco e a Chapada Diamantina". Nele se descortina um quadro desolador de fome, violência/jaguncismo, fanatismo, clientelismo político, coronelismo, enfim, de forma pioneira, um quadro quem depois, é trabalhado como constituidor do imagético/discursivo do Nordeste brasileiro. Todavia, avulta também nessa obra, um Brasil pouco conhecido para a sua maioria, como dotado de uma beleza incomensurável e cheia de possibilidades. Teodoro Sampaio é a sua circunstância histórica, como bem ressalta Ortega e Gasset: acreditou numa modernização e numa inclusão social, dentro de um mundo positivista crente na fé do progresso técnico, no bojo do mercado. Nesta perspectiva buscou estudar, planejar e executar uma série de obras e estudos que viessem criar condições de desenvolvimento inclusivo; ou seja, numa perspectiva "iluminada", acreditou que as elites podiam encampar um processo de formação territorial que incluísse, num futuro, a população de renegados. Mirando o presente, mesmo não tendo o Brasil se realizado a contento por essa via, o legado de Teodoro Sampaio Está vivo no aqui e agora, no espaço atual, pelo que vislumbrou: a chegada de mais civilização, ou seja, menos coronelismo, menos violência pessoal e coletiva, menos clientelismo e mais atenção a criação de um sistema de objetos e de ações mais equânimes e justo.

\section{REFERÊNCIAS}

ALBUQUERQUE JÚNIOR, Durval Muniz de. A invenção do Nordeste e outras artes. Recife: Massangana; São Paulo: Cortez, 1999

BAUMAN, Zygmunt. Modernidade líquida. Rio de Janeiro: J. Zahar, 2004.

CINTRA, J. P. E SILVA, M. J. F. Teodoro Sampaio e o Início da Cartografia Sistemática no Brasil. Relatório de Iniciação Científica PIBIC-CNPQ 2000/2001. EPUSP - PTR, São Paulo.

FREIRE, Paulo. Pedagogia do Oprimido. Rio de Janeiro: Paz e Terra, 1987

ORTEGA Y GASSET, José. A Rebelião das Massas. São Paulo: Martins Fontes, 2002.

ORTEGA Y GASSET, José. Em Torno a Galileu: Esquemas das Crises. Petrópolis-RJ: VOZES, 1989

SAMPAIO, Teodoro. O rio São Francisco e a Chapada Diamantina. In: SANTANA, José Carlos de (Org.). São Paulo: Companhia das Letras, 2002 
SANTOS, Milton. A Natureza do Espaço: Técnica e Tempo, Razão e Emoção. São Paulo: Huctic, 1996.

SANTOS, Milton. Espaço e Método. São Paulo: Nobel, 1992. 